\title{
Paraendodontic surgery: case report
}

\author{
Cirurgia paraendodôntica: relato de caso
}

\author{
Maicon Douglas PAVELSKI ${ }^{1}$ \\ Danielle PORTINHO² \\ Artur CASAGRANDE-NETO3 \\ Geraldo Luiz GRIZA² \\ Rodrigo Gonçalves RIBEIRO²
}

\section{ABSTRACT}

Paraendodontic surgeries have been increasingly used to solve problems related to failures in conventional endodontic treatment. Better anatomical knowledge of the structures as well as the development of techniques and materials involved has resulted in substantial paraendodontic surgery increase and success. In some cases, teeth endodontic treatment highly benefits treatment accomplishment. This report describes a case of an endodontic treatment complemented by paraendodontic surgery in periapical region of 21, 22 and 23 of a female patient who had been treated at the clinic of the Brazilian Dental Association Dentistry - in the city of Cascavel, State of Parana, Brazil. The case presents a 12-month follow-up for the resolution of painful symptoms, lesion reduction, and bone formation. Literature review was performed regarding paraendodontic surgery in order to assess the determining factors, failure causes and procedure indications/ contraindications, as well.

Indexing terms: Apicoectomy. Endodontics. Periapical abscess. Periapical surgery. Radicular cyst.

\section{RESUMO}

A cirurgia paraendodôntica tem sido cada vez mais utilizada para sanar problemas inerentes aos insucessos no tratamento endodôntico convencional. O melhor conhecimento anatômico das estruturas envolvidas bem como a evolução das técnicas e dos materiais proporcionou um aumento significativo da utilização desta técnica e, por conseguinte seu maior sucesso. O tratamento endodôntico primário de um elemento dentário pode atingir altos índices de sucesso. Tornando-se, portanto, imprescindível para se atingir o sucesso do tratamento de alguns casos. Neste trabalho descreve-se um caso de tratamento endodôntico complementado por cirurgia paraendodôntica em região periapical dos elementos dentais 21, 22 e 23 de paciente do gênero feminino que foi tratada na Clínica de Odontologia da Associação Brasileira de Odontologia - Regional de Cascavel, Pr. O caso apresenta acompanhamento de 12 meses com resolução da sintomatologia dolorosa, redução da lesão e neoformação óssea. Foi realizada uma discussão com revisão da literatura sobre a cirurgia paraendodôntica avaliando os fatores determinantes, causas de insucessos, indicações e contraindicações do procedimento.

Termos de indexação: Apicectomia. Endodontia. Abcesso periapical. Cirurgia periapical. Cisto radicular.

\section{INTRODUCTION}

Endodontic pathology has inflammatory origin and it is closely related to microbial contamination of root canals. The complexity of dental anatomy may exacerbate and further complicate this pathology.

Dental pulp is in close contact with the periodontium, either due to the presence of the apical foramen, lateral canals, accessory canals, and apical delta and inter-radicular canal, or by root perforations? ${ }^{1}$.

Endodontic infection occurs as a result of pulp necrosis along with host defense decrease or after pulp removal, during endodontic treatment. Bacteria are the main etiologic issue related to this dental infection. However, fungus, archaea and virus presence were also described in the periapical pathogenesis. The inflammation of periradicular tissue develops due to bacterial product effects and its progression is caused by host factors and bacterial population².

Paraendodontic surgery, which was conceived in Germany in the mid-1890s, has been increasingly used in order to solve problems con cerning conventional endodontic treatment failures. The necrotic apex removal technique has been improved by new surgical procedures

\footnotetext{
${ }^{1}$ Universidade Estadual do Oeste do Paraná, Residente do Serviço de Cirurgia e Traumatologia Bucomaxilofacial do Hospital Univeristário. Cascavel, PR, Brasil.

${ }^{2}$ Universidade Estadual do Oeste do Paraná, Curso de Odontologia. Cascavel, PR, Brasil. Rua Universitária, 2069, Jardim Universitário, 85819-110, Cascavel - PR, Brasil. Correspondência para / Correspondence to: D PORTINHO. E-mail: <danielleportinho@hotmail.com>.

${ }^{3}$ Associação Brasileira de Odontologia, Regional Cascavel. Cascavel, PR, Brasil.
} 
as well as new supporting materials applied in the apical surgical treatments ${ }^{2}$.

Nowadays, the paraendodontic surgery has been widely used in the dental clinic. Initiated in the 1990s, the endodontic microsurgery has been improved. Better understanding of the apical anatomy together with the development of ultrasonic instruments as well as the development of procedures and biomaterials, have triggered successful treatment increase (58 - 98\%) and the prognosis for teeth treated with this technique ${ }^{3}$.

Despite improvement of root canal restoration and materials used, the conventional endodontic treatment is subject to failure due to the various steps required to perform the procedure, and success has been around $65 \%$ to $90 \%{ }^{4}$.

The endodontic procedure prognosis depends on facts based on the patient's health history, the tooth itself and the treatment used, as well. Understanding these issues is crucial for the choice methodology of different treatment available ${ }^{4-5}$.

Traditional practices generally do not ensure success predictability due to the inaccessibility of all apical ramifications, as well as their cleaning and sealing. This problem was solved through microscope-assisted new techniques which allowed better lighting and visualization of the region to be treated and therefore smaller and more conservative apical resections and more accurate preparation and restorations ${ }^{3}$.

Although techniques have improved, cases of non-remission of signs and symptoms are still found and paraendodontic surgery may be used as a supplementary treatment. Thus, this study reports the case of a patient, whose conventional endodontic treatment did not succeed, requiring additional surgery was required.

\section{CASE REPORT}

A 34 year- old female patient, leukoderma, was attended in the Endodontics Dental Clinic Specialization of the Brazilian Dentistry Association - Cascavel Unit (ABO-Cascavel, State of Parana, Brazil) presenting painful symptoms in tooth \#22. The patient signed a treatment authorization, as well as a consent document, allowing the scientific radiography release and other additional examinations.

In her medical history, she had reported heart murmur and hepatitis $B$, with no other alterations that could prevent or impair the treatment. At clinical examination, the patient reported pain at palpation in the apical region of tooth \#22 and negative response to thermal tests for teeth \#21, 22, and 23. The radiographic observations showed previous endodontic treatment of tooth \#21 and wide periapical lesion in the anterior region, with possible disruption of the cortical bone.

The patient was referred for CT examination of volumetric acquisition, with seated patient, parallel to the ground occlusal plane, and a distance of $1.0 \mathrm{~mm}$ between each cut. The CT scan revealed a hypodense image within the anterior maxillary region involving the apical region of teeth \#21, 22, 23, and 24, measuring $28.5 \times 18 \times$ $15 \mathrm{~mm}$ (width, height, depth), with disruption of the vestibular and palatal cortical bones (Figure 1). Thereafter endodontic retreatment of tooth \#21 and endodontic treatment of teeth \#22 and \#23 were indicated. Dressing was changed during 4 months. Due to no pain or injury reduction, the patient was referred to paraendodontic surgical treatment.

Antibiotic prophylaxis was applied using $1 \mathrm{~g}$ amoxicillin, one hour before surgery. After extra and intra oral antisepsis, the procedure began using mepivacaine hydrochloride at 2\% with epinephrine 1:100.000 local anesthesia (DFL, Rio de Janeiro, Brazil) by blocking the left infraorbital nerve, additional infiltrative anesthesia in apexes of the teeth $\# 11,21,22,23,24$ and 25 and the blocking of the nasopalatine nerve. An intrasulcular incision was made with a scalpel blade number 15, extending from the distal of tooth \#11 to the distal of tooth \#25, with a relaxing incision in this region. The Molt Periosteal Elevator \#9 was used for injury access and cortical bone disruption confirmed. It was observed that the lesion cyst type was attached to the vestibular mucosa. The surgical specimen measuring $22 \mathrm{~mm} \times 11 \mathrm{~mm} \times 7 \mathrm{~mm}$ was removed with the aid of a curette, stored in a plastic container with $10 \%$ formalin and sent to the Histopathology Laboratory of the State University of West of Paraná for histopathological examination. After lesion removal, with aid of the Zekrya drill, apicoectomy was performed, with the removal of $2 \mathrm{~mm}$ of the apex of teeth \#21 and 22 and $3 \mathrm{~mm}$ of apex of tooth \#23, which presented visible resorption craters in the apical cementum. Throughout the apical removal procedure, intense irrigation with saline solution was made for cooling and washing of the surgical cavity, complete removal of necrotic debris, bone scrapes, and root apex was performed. With the aid of an ultrasound and using an angled ultrasonic tip, the cavity was prepared for retrofilling with Endodontic Sealer 26. The sealer was 
applied to the cavity with the aid of a spoon scavator, and press-condensed with a moistened cotton ball. The flap was repositioned and sutured with 4-0 Vicry| ${ }^{\mathrm{TM}}$ (Brasuture Ind. Com. Imp. Exp. Ltda., Brazil). A postoperative periapical radiograph was taken immediately after surgery. The patient received post-surgical care instructions and prescription of amoxicillin $875 \mathrm{mg}$ for 7 days, Nimesulide $100 \mathrm{mg}$ for 3 days, dipyrone $500 \mathrm{mg}$ in the first 24 hours and $0.12 \%$ chlorhexidine digluconate rinses for 7 days. After 14 days, the suture was removed.

Histopathological examination confirmed the radicular cyst diagnosis (periapical cyst) according to the following histological features: stratified squamous non-keratinized epithelium (largely changed caused by inflammation); fibrous connective tissue capsule with severe inflammatory infiltrate (predominantly chronic). Presence of some phagocytic cells, lots of newly-formed blood vessels and the presence of trabecular bone fragment (Figure 2).

Treatment follow-up was conducted with radiographs taken immediately after surgery (02/2015) and monitoring after 5 and 12 months (Figure 3).
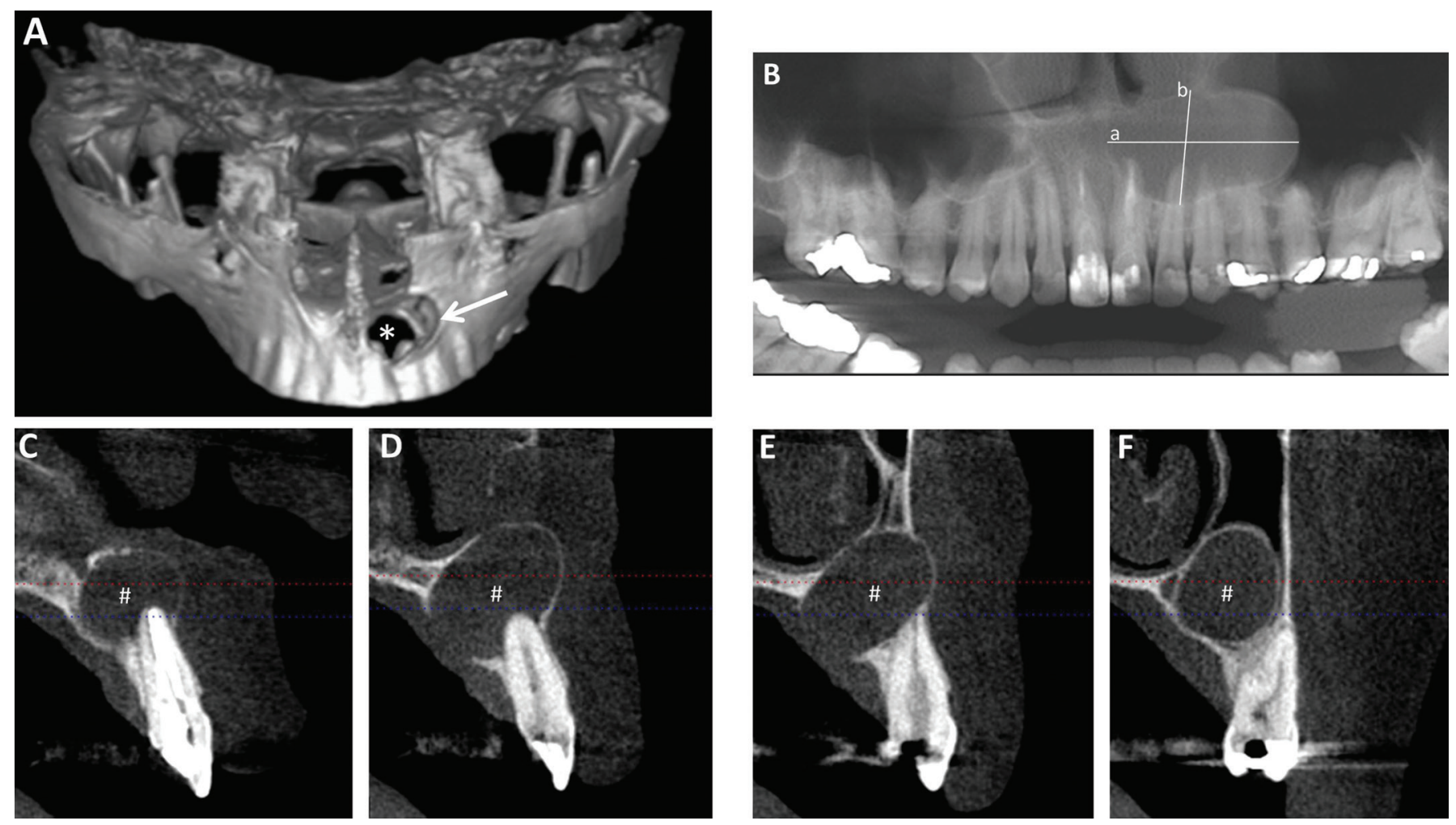

Figure 1. Tomographic image of the lesion region. (1A) anteroposterior $3 \mathrm{D}$ image showing apical lesion of the anterior teeth with vestibular $(\rightarrow)$, palatal $(*)$ and cortical bone disruptions. (1B) damage extent of the apical region from the mesial of tooth \#21 to the distal tooth \#24 (a = $28.5 \mathrm{~mm}$ and b = $18 \mathrm{~mm})$. (1C-F) sagittal sectioning of injury, covering teeth \#21, 22, 23 and 24 , respectively.
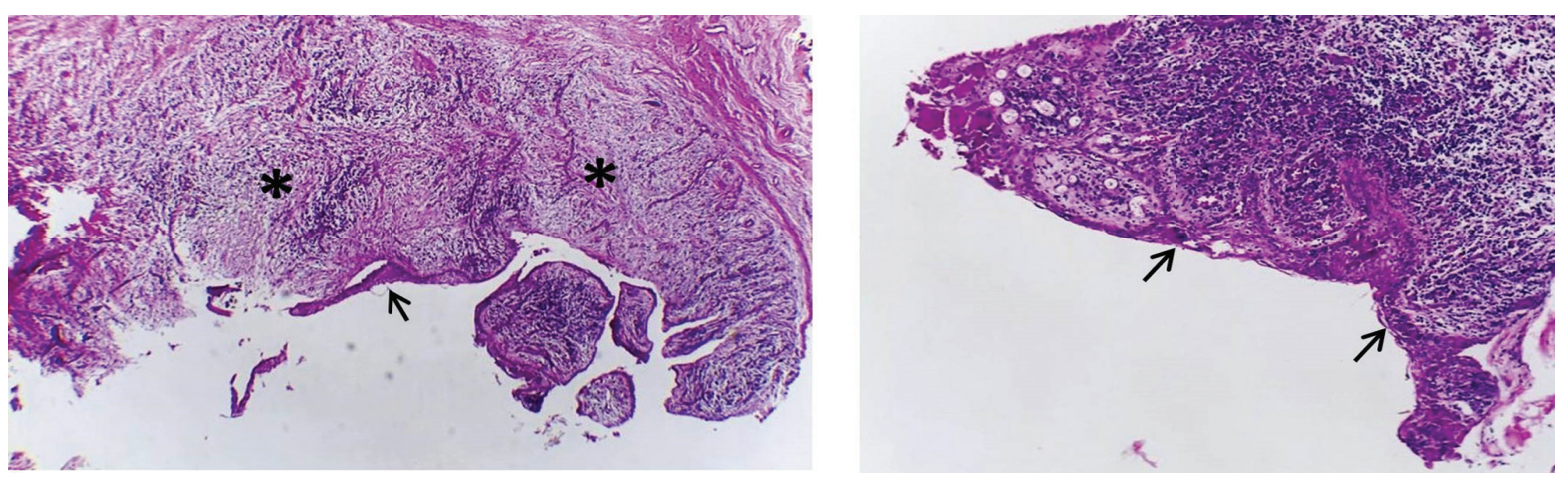

Figure 2. Histopathological image of radicular cyst. The images show the cyst with its cystic capsule $(*)$ coated by stratified squamous non-keratinized epithelium $(\rightarrow)$. A large amount of inflammatory infiltrate is observed. H.E. staining (A) 10x and (B) 40x. 

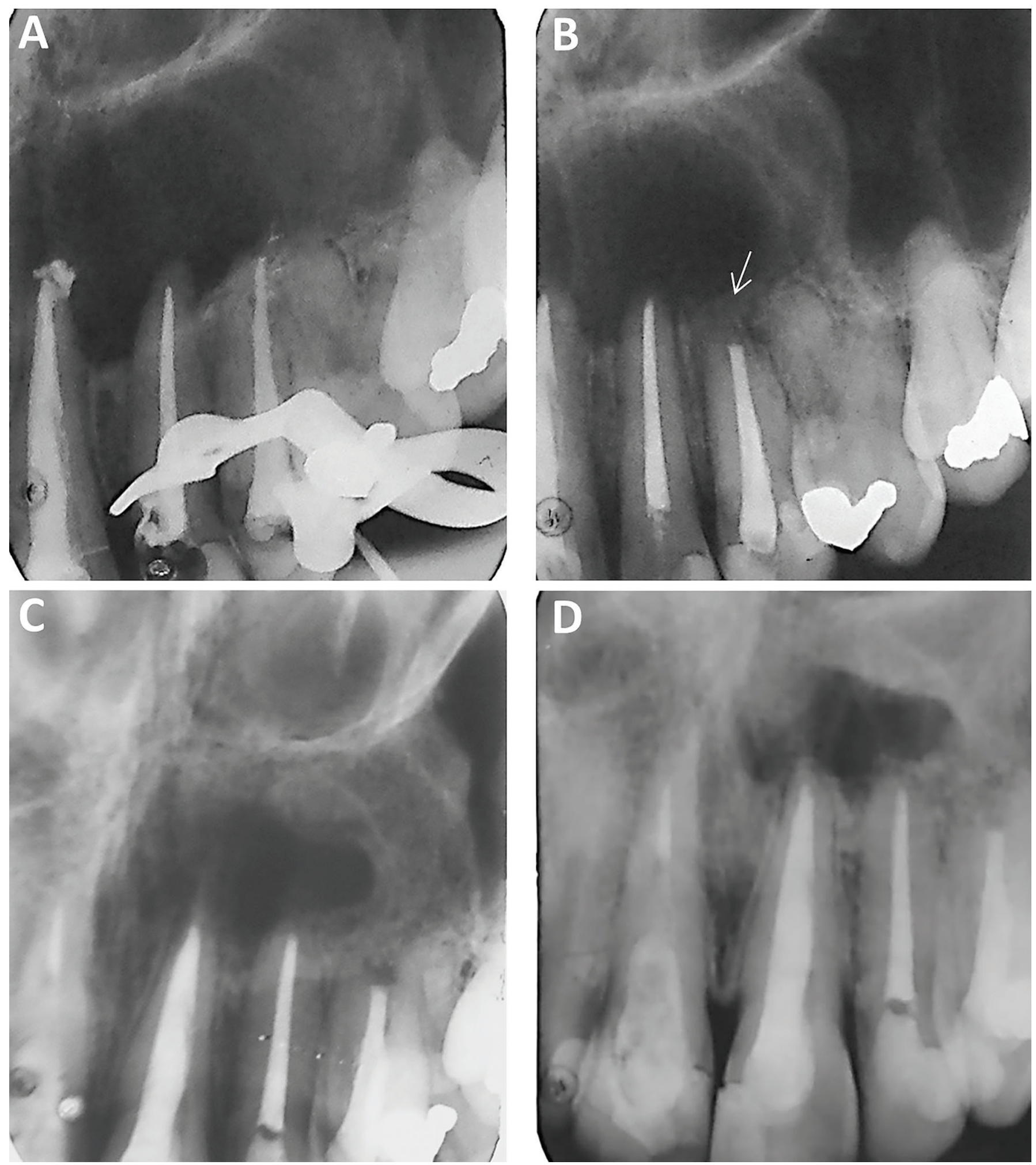

Figure 3. Radiographic images. (1A) retreatment of tooth \#21 and treatment of teeth \#22 and \#23. (1B) Radiography taken immediately after paraendodontic surgery. The figure shows the apex of tooth \# after apicectomy $(\rightarrow)$. (1C) preservation after 5 months of the surgery. (1D) preservation after 12 months of the surgery. The image shows considerable reduction of apical lesions with bone neoformation. 


\section{DISCUSSION}

The primary endodontic treatment of a tooth may lead to high successful rates ${ }^{3}$. When performing this procedure, at the time of intervention, the Endodontics specialist is not aware of the histological status of the periapical lesion. The injury kind and treatment success are strongly related. Some authors claim that periapical granuloma responds well to conventional treatment, however it is known that periapical cysts usually do not regress, resulting in treatment failure ${ }^{6-7}$. Nair ${ }^{7}$, also states that about $15 \%$ of periapical radiolucent corresponds to some kind of cyst; thus, approximately $10 \%$ of periapical lesions require surgical treatment associated with endodontic therapy.

In the case of endodontic retreatment, the success rate is lower than the ones of the primary treatments ${ }^{8}$. In addition, about 5 to $25 \%$ of the teeth classified as healed after one year, may regress and show periapical radiolucency as well as symptomatology again after a long period ${ }^{5}$.

Periapical surgical treatment has been increasing since it is a more conservative handling method for teeth presenting intraradicular retainer and prosthetic crowns associated with periapical lesions. Often, the removal of the post and core set covered with prosthetic crown for subsequent endodontic retreatment is more traumatic and may delay treatment completion?.

The paraendodontic surgery should only be recommended after conventional endodontic treatment or when the prognosis is obscure ${ }^{4}$. In case of failure, the retreatment would be the first option for previously treated roots, which are still symptomatic or have periapical lesions ${ }^{10}$. However, the authors recommend that teeth presenting apical periodontitis, and which have been already submitted to conventional treatment should always be apicectomized rather than undergo a simple smoothing and/or apical rounding ${ }^{11}$. A last option for the maintenance of these teeth is the surgery, in some cases. When the failure of conventional treatment is verified and when the removal of the causative agent via endodontium is impossible or contraindicated, the paraendodontic surgery is the treatment of choice ${ }^{10,12}$. Kuga et al. ${ }^{13}$, further add that cases in which the initial treatment becomes doubtful, root perforations and the presence of foreign bodies in periapical tissue would also become indications of this type of procedure. Irremovable pin retained restorations and pulp calcifications in the middle and cervical third are also indications cited in the bibliography ${ }^{4}$. Moreover, during retreatment it is difficult to obtain dry root canals due to the presence of periapical lesions or root perforations. In such cases, the paraendodontic surgery enables the removal of periapical lesions, thereby reducing the periapical inflammatory exudate. Thus, paraendodontic surgery favors the establishment of dry root canals for endodontic treatment $1^{13}$.

One explanation for the resistance to treatment of periapical endodontic lesions is that periapical cysts may turn into true cysts. Thus, apart from the root apex it is impossible to achieve success through traditional endodontic treatment. In these cases, there is a consensus that cysts associated with the root apex regress completely after endodontic therapy and true cysts that are separated from the dental root must be surgically removed ${ }^{6-7}$.

Kuga et al. ${ }^{14}$ assert that the periapical curettage is needed in order to optimize the healing of the periapical pathological process, since it eliminates the infected granulomatous tissue and removes foreign bodies such as fractured instruments and sealer extravasation debris. The same authors, in $1992^{13}$, claim that the root canal obturation, concomitant with the surgery, is an excellent alternative. The process improves the root canal biomechanics, stops apical extravasation of obturation material and allows more efficient filling due to more vigorous condensation, thus reaching more collaterals and secondary canals providing decreasing failure chances.

The success rates may be increased with the use of electron microscopes and ultrasonic tips, which provide a better visualization of the operative field and a more precise and conservative preparation ${ }^{15-16}$. The introduction of the principles of microsurgery and new retro-filling materials increased success rates; however, complete healing of the apical region is still around $80 \%$ to $90 \%{ }^{10}$. Other studies show that $37 \%$ to $85 \%$ of the teeth have complete healing after surgery; on the other hand, $33 \%$ of the studied teeth may remain in healing process for years after surgery. Even if not completely healed, $80 \%$ to $94 \%$ of the teeth may not be symptomatic ${ }^{17}$. These results may reflect the lack of methodological standardization in the research and the large amount of variables involved to achieve treatment success.

The predictability of the results is directly related to the preoperative evaluation of the case. The prognosis of apical surgery4 may be influenced by the patient's systemic condition, the tooth involved, amount and location of bone resorption and degree of occlusal microinfiltration of restorations. 
For von Arx et al. ${ }^{18}$, factors related to patients were not significantly correlated with alterations in healing, however, the professional must be alert to systemic conditions or locations that may affect tissue repair. There is consensus among many authors that what most affects the outcome of periapical surgery is related to the tooth itself. The presence of previous pain and quality of the coronal restoration are associated with higher failure rates ${ }^{10,16,19}$. A potential infiltration of the filling material may negatively affect the periradicular microenvironment, influencing the final result of the treatment ${ }^{20}$. Moreover, the presence of inflammation and prior edema may affect local healing and impair the complete bacterial clearance, which would increase the risk of recurrent infections ${ }^{21}$. For Tobon-Arroyave et al. ${ }^{22}$ the factor that most affects the treatment is the type of apical filling material and its correct application. For them, the correct filling and apical sealing prevent bacterial inflow to periapical tissues. The retrofilling materials should ideally possess the capability of apical sealing, biocompatibility and promote regeneration of previously injured periapical tissues. Currently, the closest material to such features is the Mineral Trioxide Aggregate (MTA), considered the gold standard for this purpose, as the only one to promote the cementum regeneration of the sealed ape ${ }^{23}$. MTA also has excelled other materials by offering better adaptation to the dentinal walls and require less force for its condensation. Materials such as amalgam and IRM have fallen into disuse because of their low long-term clinical efficacy. Portland cement could have been used due to its low cost, but it is a material with limited radiopacity ${ }^{24}$.

Rud et al. ${ }^{25}$, already defended the monitoring of cases treated surgically for a minimum period of four years. This monitoring is defensible since about $5 \%$ to $25 \%$ of teeth classified as healed may, after a year, present periapical radiolucency and symptoms again and should, therefore, be part of long-term follow-up ${ }^{5}$. It should also be pointed out that the formation of a fibrous scar can occur in more than $10 \%$ of the cases treated with paraendodontic surgery and the correct diagnosis must be made so that these cases are

\section{REFERENCES}

1. Maniglia CAG, Picoli F, Maniglia AB. Estudo infiltrativo da prevalência de canais acessórios na região de furca de molares inferiores e superiores humanos. Rev. Fac. Odontol. 2004;16(1):4146.

2. Cohen S, Hargreaves KM. Caminhos da Polpa. 9a ed. Rio de Janeiro: Guanabara; 2011. not mistakenly considered as failures.

The success of paraendodontic surgery is related to the interaction between several factors, which include correct indication of the procedure and the surgical technique performance, the type of retro obturator material used and quality of the initial obturation, adequate treatment of the surgical cavity and previous periodontal conditions ${ }^{12}$.

However, there is still a pre-established protocol for treatment choice, which must be, wherever possible, individualized and based on case prognosis. The most relevant teeth related factors are: the absence of signs and symptoms; good density of root obturation and apical periodontitis lower or equal to $5 \mathrm{~mm}$. Teeth treated with endoscope aid have higher rates of success than naked-eye treated teeth ${ }^{5}$.

\section{CONCLUSION}

The paraendodontic surgery is a viable alternative to solve cases where the conventional endodontic treatment proves to be ineffective.

Technologies related to the materials and surgical techniques are constantly being developed in order to make them simpler and bring greater success predictability.

\section{Collaborators}

PORTINHO D was responsible for article writing idea, photographic documentation, preparation of figures and monitoring of clinical case. PAVELSKI MD was responsible for surgery, literature review, idea and write of the article and clinical follow-up. CASAGRANDE-NETO A was responsible for literature review, diagnosis, retreatment and endodontic treatment. GRIZA GL was responsible for paraendodontic surgery and clinical follow-up. RIBEIRO R was responsible for assistance in the writing of article, diagnosis and monitoring of the case.

All authors contributed and approved the manuscript.

3. Kim S, Kratchman S. Modern endodontic surgery concepts and practice: a review. J Endod. 2006;32(7):601-23. doi: http://dx.doi. org/10.1016/j.joen.2005.12.010

4. Almeida-Filho J, Almeida GM, Marques EF, Bramante CM. Cirurgia paraendodôntica: relato de caso. Oral Sci. 2011;3(1):21-25.

5. Azarpazhooh A, Shah PS. Endodontic surgery prognostic factors. Evid Based Dent. 2011;12(1):12-13. doi: 10.1038/sj.ebd.6400773.

6. Nair PN. Non-microbial etiology: foreign body reaction main 
taining post-treatment apical periodontitis. Endod Topics. 2003;6(1):114-134. doi: 10.1111/j.1601-1546.2003.00052.x.

7. Nair PN. Pathogenesis of apical periodontitis and the causes of endodontic failures. Crit Rev Oral Biol Med. 2004;15(6):348-381. doi: 10.1177/154411130401500604.

8. Gorni FG, Gagliani MM. The outcome of endodontic retreatment: a 2-yr follow-up. J Endod. 2004;30(1):1-4. doi: 10.1097/00004770-20040100000001

9. Wang N, Knight K, Dao T, Friedman S. Treatment outcome in endodontics: the Toronto Study. Phases I and II: apical surgery. J Endod. 2004;30(11):751-6. doi: 10.1097/01. don.0000137633.30679.74.

10. Villa-Machado PA, Botero-RAMIREZ X, Tobon-Arroyave SI. Retrospective follow-up assessment of prognostic variables associated with the outcome of periradicular surgery. Int Endod J. 2013;46(11):1063-76. doi: 10.1111/iej.12100

11. Oliveira CJ, Lemos SR. Cirurgia paraendodôntica: como realizála com embasamento técnico-científico. Instituto de Estudos da Saúde. [monografia]. Belo Horizonte: 2009. 82p.

12. Fagundes RB, Prado M, Gomes BPFA, Damé JAM, Sousa ELR. Cirurgia parendodôntica: uma opção para resolução de perfuração radicular: apresentação de caso clínico. Rev Odontol UNESP. 2011;40(5):272-277.

13. Kuga MC, Tanomaru Filho M, Bramante CM, Nishiyama CK. Cirurgia parendodôntica com obturação simultânea dos canais radiculares. Rev Assoc Paul Cir Dent. 1992;46:817-20.

14. Kuga MC, Okamoto T, Brito JRO, Riberio Júnior PD, Tanaka H. Cirurgia paraendodônticas em função de modalidades cirúrgicas e tempo de controle. Rev Assoc Paul Cir Dent. 1997;51:136-40.

15. Abramovitz I, Better H, Shacham A, Shlomi B, Metzger Z. Case selection for apical surgery: a retrospective evaluation of associated factors and rational. J Endod. 2002;28(7):527-530. doi: 10.1097/00004770-200207000-00010.

16. Von Arx T, Jensen SS, Hänni S. Clinical and radiographic assessment of various predictors for healing outcome 1 year after periapical surgery. J Endod. 2007;33(2):123-128. doi: 10.1016/j. joen.2006.10.001.

17. Friedman S. Prognosis and expected outcome of apical surgery. Endodontic Topics 2005;11:219-262. doi: 10.1111/j.16011546.2005.00187.x
18. von Arx $T$, Peñarrocha $M$, Jensen $S$. Prognostic factors in apical surgery with root-end filling: a meta-analysis. J Endod. 2010;36(6):957-973. doi: 10.1016/j.joen.2010.02.026.

19. Rahbaran S, Gilthorpe MS, Harrison SD, Gulabivala K. Comparison of clinical outcome of periapical surgery in endodontic and oral surgery units of a teaching dental hospital: a retrospective study. Oral Surg Oral Med Oral Pathol Oral Radiol Endod. 2001;91(6):700-709. doi: 10.1067/moe.2001.114828.

20. Barbosa HG, Holland R, Souza V, Dezan-Júnior E, Bernabé PFE, Otoboni-Filho JA, et al. Healing process of dog teeth after post space preparation and exposition of the filling material to the oral environment. Braz. Dent. J. [periódico na Internet]. 2003 [acesso 2016 Feb 23];14(2):103-108. Disponível em: http://www.scielo.br/scielo.php?script=sci_arttext\&pid=S010364402003000200006\&lng=en. doi: 10.1590/S010364402003000200006 .

21. Nair PN. On the causes of persistent apical periodontitis: a review. Int. Endod. J. 2006;39(4):249-281. doi: 10,1111/j.13652591.2006.01099.x.

22. Tobon-Arroyave SI, Restrepo-Perez MM, Arismendi-Echavarria JÁ, Velasquez-Restrepo Z, Marin-Botero ML, García-Dorado EC. Ex vivo microscopic assessment of factors affecting the quality of apical seal created by root-end fillings. Int Endod J. 2007;40(8):590-602. doi: 10.1111/j.1365-2591.2007.01253.x.

23. Torabinejad M. Commentary by Mahmoud Torabinejad histologic assessment of mineral trioxide aggregate as a root-end filling in monkeys. Int Endod J. 2009;42(5):406-407. doi: 10.1111/j.13652591.2008.01523.x.

24. Almeida MS, Castro-Silva IL, Bittencourt RC, Almeida PBA, Granjeiro JM. Radiopacidade de novos biomateriais usados em cirurgia paraendodôntica. Pesq Bras Odontoped Clin Integr. 2011;11(4):465-469. doi: 10.4034/PBOCI.2011.114.01.

25. Rud J, Andreasen JO, Jensen JF. A multivariate analysis of the influence of various factors upon healing after endodontic surgery. Int J Oral Surg. 1972;1(5):258-271. doi: 10.1016/S03009785(72)80045-0. 